\title{
PENGARUH AKTIVITAS OLAHRAGA TRADISIONAL TERHADAP KECEPATAN LARI 40 METER PADA SISWA KELAS V SD NEGERI 029 LOA JANAN
}

\author{
Nurjamal \\ Universitas Mulawarman, email : nurjamal.unmul@gmail.com \\ Muh.Taufiq Hidayat \\ Universitas Mulawarman, email : Hidayatmus0@Gmail.com \\ Muh.Ramli Buhari \\ Universitas Mulawarman, email : ramlipjkr@gmail.com \\ Muchamad Samsul Huda \\ Universitas Mulawarman, email : mshudari@gmail.com
}

\begin{abstract}
Abstrak
Penelitian ini bertujuan untuk mengetahui apakah ada pengaruh aktivitas olahraga tradisional terhadap kecepatan lari 40 meter pada siswa kelas V SD Negeri 029 Loa Janan. Jenis penelitian ini adalah eksperimen lapangan dengan melibatkan dua variable bebas yaitu olahraga tradisional polisi vs maling dan olahraga tradisional bentengan dan variable terikat yaitu lari 40 meter Populasi dalam penelitian ini adalah seluruh siswa/i SD Negeri 029 Loa Janan yang berjumlah 13 orang Teknik analisis data yang digunakan adalah statistik deskriptif dan statistic inferensial dengan menggunakan teknik uji t-test. Berdasarkan analisis data diperoleh hasil : (1) Nilai t-hitung > nilai t-tabel, $9.354>1.943$ atau ada pengaruh aktivitas olahraga tradisional polisi vs maling terhadap kecepatan lari 40 meter terhadap kecepatan lari 40 meter pada siswa kelas V SD Negeri 029 Loa Janan. (2) Nilai thitung > nilai t-tabel, $7.348>2.015$ atau ada pengaruh aktivitas olahraga tradisional bentengan terhadap kecepatan lari 40 meter pada siswa kelas V SD Negeri 029 Loa Janan. (3) Nilai t-tabel > nilai t-hitung,1.796 $>0.070$ atau tidak ada perbedaan pengaruh antara aktivitas olahraga tradisional polisi vs maling dan bentengan terhadap kecepatan lari 40 meter pada siswa kelas V SD Negeri 029 Loa Janan,.Dengan demikian aktivitas olahraga tradisional polisi vs maling dan aktivitas olahraga tradisional bentengan saling memiliki pengaruh yang baik terhadap kecepatan lari 40 meter pada siswa kelas V SD negeri 029 Loa Janan.
\end{abstract}

Kata Kunci: Polisi vs maling, Bentengan dan lari 40 meter

\begin{abstract}
The research aims to find out if there is a influence on the traditional sport activity of 40 meters in class $V$ students of elementary school 029 Loa Janan. This type of research is field experimentation by involving two free variables i.e. traditional sports police vs. theft and traditional sports clasd and variable bound i.e. running 40 meters population in this study are all students/I SD State 029 Loa Janan which amounted to 13 people data analysis techniques used are descriptive statistics and statistic inferential by using T-test test techniques. Based on the analysis of data obtained results: (1) T-count value > T-table value, 9,354 > 1,943 or there is a influence of traditional sport activity of police vs. theft to the running speed of 40 meters to the running speed of 40 meters in grade $V$ students of SD State 029 Loa Janan. (2) T-count value > T-table value, 7,348>2,015 or there is an influence of traditional sporting activity in the event of a running speed of 40 meters in class $V$ student elementary School 029 Loa Janan. (3) T-table value > T-count value, $1.796>0070$ or no
\end{abstract}


difference of influence between the traditional sports activity of police vs. theft and a fortification to a running speed of $\mathbf{4 0}$ meters in primary grade $V$ students 029 Loa Janan,. Thus the traditional sport activities of police vs. theft and the traditional sporting activities of the interlocking have a good influence on the running speed of 40 meters in the class $V$ student elementary School 029 Loa Janan.

Keywords: Police vs Maling, Vlasengan and Running 40 meter

\section{PENDAHULUAN}

Pendidikan jasmani adalah suatu pendidikan yang dilakukan secara sistematis melalui berbagai kegiatan jasmani dalam rangka memperoleh kemampuan, keterampilan jasmani, pertumbuhan, kecerdasan dan pembentukan karakter. Pada hakekatnya pendidikan jasmani adalah proses pendidikan yang memanfaatkan aktivitas fisik. Dalam proses pembelajarannya, pendidikan jasmani ditekankan pada pengembangan individu secara menyeluruh, disamping itu pendidikan jasmani tidak diarahkan untuk menguasai cabang olahraga, namun lebih mengutamakan proses perkembangan moral siswa, di sekolah dasar sendiri, materi dalam pembelajaran penjas cukup beragam ada permainan bola besar, permainan bola kecil dan atletik serta masih banyak yang lain.

Atletik merupakan induk dari seluruh cabang olahraga karena di dalam cabang olahraga atletik terdapat gerak dasar yang banyak digunakan oleh cabang olahraga lain seperti lari, lompat, lempar dan jalan. Cabang olahraga atletik memiliki beberapa nomor yang diperlombakan yaitu lari, lompat, lempar dan jalan. Atletik berasal dari kata Yunani yaitu Atlon, Atlhun yang berarti pertandingan atau perjuangan. Olahraga atletik mula-mula dipopulerkan oleh bangsa Yunani kira- kira pada abad ke- 6 SM. Orang yang berjasa mempopulerkannya adalah Iccus dan Herodicus, walaupun demikian dasarnya tetap sama yaitu, lari, lompat lempar dan jalan.
Menurut Nur Hasan (2000 : 92) dalam bukunya "Tes Dan Pengukuran Pendidikan Olahraga" mengatakan bahwa untuk mengukur kecepatan lari cepat di tingkat sekolah dasar khususnya untuk usia 10 sampai 12 tahun atau di kelas 4, 5 dan 6 yaitu dengan jarak lari 40 meter. Lari 40 meter, yaitu lari dengan sekencangkencangnya menuju garis finish. Lintasannya berbentuk lurus, rata, serta tidak licin yang berjarak 40 meter dan yang menjadi tanda awal berlari bisa berupa bendera yang diangkat, pluit atau pistol dan lari 40 meter biasanya menggunakan start bediri. Sebagai langkah awal dari peneliti, peneliti melakukan observasi ke SD 029 Loa Janan yang berupa wawancara. Wawancara yang dilakukan oleh peneliti langsung bersama guru olahraga di SD tersebut, dikatakan bahwa yang menjadi permasalahannya yaitu kurangnya minat siswa dalam mengikuti pembelajaran, khususnya pada materi lari.

Olahraga tradisional sangatlah beragam ada bentengan, polisi vs maling, patok lele, gobak sodor dan masih banyak lagi dan diantara banyaknya olahraga tradisional, olahraga tradisonal yang berkaitan erat dengan aktivitas lari yaitu bentengan dan polisi vs maling yang masing- masing memerlukan kecepatan. Aktivitas berlari dari kedua olahraga tradisional ini bisa dilihat saat melakukan olahraga bentengan yang dimana aktivitas berlarinya terdapat pada saat kedua tim mencoba untuk mengambil alih markas lawan serta berlari untuk menghindar dari lawan. Sedangkan untuk polisi vs maling terdapat pada saat tim polisi mengejar tim 
maling dan tim maling berusaha kabur dari kejaran tim polisi. Jadi bisa saja kedua olahraga ini mampu meningkatkan kecepatan lari siswa di sd tersebut. Berdasarkan uraian diatas, untuk meningkatkan kecepatan lari 40 meter siswa SD Negeri 029 maka peneliti bermaksud melakukan penelitian yang berjudul "Pengaruh Aktivitas Olahraga Tradisonal Terhadap Kecepatan Lari 40 Meter Pada Siswa Kelas V SD Negeri 029 Loa Janan Tahun Pembelajaran 2018/2019"

\section{METODE}

Penelitian ini termasuk dalam jenis penelitian eksperimen. Penelitian eksperimen adalah penelitian yang dilakukan untuk mengetahui ada tidaknya akibat dari sesuatu yang dilakukan pada subyek penelitian, dan berdasarkan dengan hipotesis yang ada maka peneliti ingin mengetahui apakah ada pengaruh aktivitas olahraga tradisonal polisi vs maling dan aktivitas olahraga tradisional bentengan terhadap kecepatan lari 40 meter pada siswa kelas $V$ SD Negeri 029 Loa Janan. Populasi dalam penelitian ini adalah seluruh siswa/I kelas $V$ SD Negeri 029 Loa Janan dan sampel dalam penelitian ini adalah seluruh siswa/I kelas V SD Negeri 029 Loa Janan yang berjumlah 13 orang.

\section{HASIL PENELITIAN DAN PEMBAHASAN Hasil penelitian}

Analisis data deskriptif dimaksudkan untuk mendapatkan gambaran umum data penelitian. Analisis deksriptif di lakukan untuk data tes awal dan tes akhir lari 40 meter pada kelompok permainan polisi vs maling (A) dan kelompok permainan bentengan (B). Rangkuman hasil analisis deskriptif data hasil penelitian tercantum dalam tabel 1 berikut ini:
Tabel 1. Hasil Analisis Deskriptif Data Tes Awal dan Tes Akhir Lari 40 Meter

\begin{tabular}{c|c|c|c|c|c|c|c}
\hline & $\mathbf{N}$ & $\begin{array}{c}\text { Ran } \\
\text { ge }\end{array}$ & $\begin{array}{c}\mathbf{M} \\
\text { in }\end{array}$ & $\begin{array}{c}\mathbf{M} \\
\mathbf{a} \\
\mathbf{x}\end{array}$ & $\begin{array}{c}\mathbf{M} \\
\mathbf{e a} \\
\mathbf{n}\end{array}$ & $\mathbf{S D}$ & $\begin{array}{c}\text { Varia } \\
\mathbf{n s}\end{array}$ \\
\hline $\mathrm{A} 1$ & 7 & 1.4 & 1 & 1 & 16 & 0. & 0.199 \\
& & 7 & 5. & 6. & .0 & 44 & \\
& & & 2 & 7 & 68 & 6 & \\
\hline $\mathrm{A} 2$ & 7 & 1.4 & 1 & 1 & 16 & 0. & 0.198 \\
& & 8 & 5. & 6. & .0 & 44 & \\
& & & 2 & 6 & 28 & 4 & \\
\hline $\mathrm{B} 1$ & 6 & 1.0 & 1 & 1 & 15 & 0. & 0.182 \\
& & 4 & 5. & 6. & .9 & 42 & \\
& & & 3 & 4 & 53 & 7 & \\
\hline B2 & 6 & 1.0 & 1 & 1 & 15 & 0. & 0.191 \\
& & 7 & 5. & 6. & .8 & 43 & \\
& & & 3 & 3 & 97 & 6 & \\
& & & 1 & 8 & & & \\
\hline
\end{tabular}

Tabel di atas menunjukan hasil rangkuman analisis deskriptif data tes awal dan akhir kecepatan lari 40 meter pada kelompok polisi vs maling dan kelompok bentengan. Pada analisis deskriptif data tes awal kelompok polisi vs maling, diperoleh nilai rata-rata 16.068 detik, standar deviasi 0.446 detik, varians 0.199 detik, nilai minimum 15.26 detik, nilai maksimum 16.73 detik dan rentang 1.47 detik. Sedangkan untuk analisis deskriptif data tes akhir kelompok polisi vs maling, diperoleh nilai rata-rata 16.028 detik, standar deviasi 0.444 detik, varians 0.198 detik, nilai minimum 15.21 detik, nilai maksimum 16.69 detik dan rentang 1.48 detik. Pada analisis deskriptif data tes awal kelompok bentengan, diperoleh nilai ratarata 15.953 detik, standar deviasi 0.427 detik, varians 0.182 detik, nilai minimum 15.39 detik, nilai maksimum 16.43 detik dan rentang 1.04 detik, sedangkan untuk analisis deskriptif data tes akhir kelompok bentengan, diperoleh nilai rata-rata 15.897 detik, standar deviasi 0.436 detik, varians 0.191 detik, nilai minimum 15.31 detik, 
nilai maksimum 16.38 detik dan rentang 1.07 detik.

Setelah nilai rata-rata dan simpangan baku kedua kelompok sampel diketahui, maka langkah selanjutnya adalah melakukan uji normalitas dari data hasil tes tersebut dengan menggunakan uji Shapiro wilk. Tujuannya yaitu untuk menetapkan teknik pengujian hipotesis,apakah data berdistribusi normal atau tidak. Jika data berdistribusi normal, maka menggunakan pengujian parametric dan sebaliknya jika data berdistribusi tidak normal, maka menggunakan pengujian non parametric.

Tabel 2. Hasil Uji Normalitas Shapiro Wilk Kedua Kelompok

\begin{tabular}{l|c|c|c|c|c}
\hline \multicolumn{2}{c|}{ Kelompok } & \multicolumn{4}{c}{ Shapiro Wilk } \\
\cline { 2 - 6 } \multicolumn{2}{c|}{} & $\begin{array}{c}\text { Statist } \\
\text { ik }\end{array}$ & $\begin{array}{c}\text { D } \\
\text { f }\end{array}$ & Sig. & $\begin{array}{c}\text { Keterang } \\
\text { an }\end{array}$ \\
\hline $\begin{array}{l}\text { Lari } \\
40 \\
\begin{array}{l}\text { Mete } \\
r\end{array}\end{array}$ & A1 & 0.950 & 7 & $\begin{array}{l}0.73 \\
8\end{array}$ & Normal \\
\cline { 2 - 6 } & A2 & 0.921 & 7 & $\begin{array}{l}0.51 \\
6\end{array}$ & Normal \\
\cline { 2 - 6 } & B1 & 0.851 & 6 & $\begin{array}{l}0.16 \\
2\end{array}$ & Normal \\
\cline { 2 - 6 } & B2 & 0.869 & 6 & $\begin{array}{l}0.22 \\
2\end{array}$ & Normal \\
\hline
\end{tabular}

Berdasarkan tabel 2 diatas maka diperoleh gambaran bahwa pengujian normalitas data sebagai berikut: Pada tes awal lari 40 meter untuk kelompok polisi vs maling diperoleh nilai sig $=0,738(\mathrm{P})$ $0,05)$, maka hal ini menunjukkan bahwa tes awal lari 40 meter kelompok polisi vs maling berdistribusi normal. Sedangkan data tes akhir lari 40 meter kelompok polisi vs maling diperoleh nilai sig $=0,516$ detik $(P>0,05)$, maka hal ini menunjukkan bahwa data tes akhir lari 40 meter pada kelompok polisi vs maling berdistribusi normal.Pada tes awal lari 40 meter untuk kelompok bentengan diperoleh nilai sig $=$ $0,162(P>0,05)$ maka hal ini menunjukkan bahwa datates awal lari 40 meter pada kelompok bentengan berdistribusi normal.
Sedangkan data tes akhir lari 40 meter pada kelompok bentengan diperoleh nilai sig $=0,222(\mathrm{P}>0,05)$ maka hal ini menunjukkan bahwa data tes akhir lari 40 meter pada kelompok bentengan berdistribusi normal.

Tabel 3. Paired Sampel T-Test Pada Hasil Eksperimen Tes Awal dan Tes Akhir Kelompok Polisi vs Maling.

\begin{tabular}{c|c|c|c|c|c}
\hline $\begin{array}{c}\text { Variab } \\
\text { el }\end{array}$ & Mean & SD & $\begin{array}{c}\text { t- } \\
\text { hitu } \\
\text { ng }\end{array}$ & $\begin{array}{c}\text { t-tabel } \\
(0,05: 6)\end{array}$ & Sig \\
\hline A1 - A2 & 0.500 & 0.1 & 9.3 & 1.943 & .00 \\
& & 41 & & & 0 \\
\hline
\end{tabular}

Dari hasil pengujian hipotesis komparatif rata-rata dua sampel pada tabel 3 di atas diperoleh rata-rata sebelum dan sesudah diberi perlakuan berupa olahraga tradisional polisi vs maling sebesar $=0.500$ dengan standar deviasi $=$ 0.141 , t-hitung $=9.354$ dengan derajat kebebasan 6 pada taraf signifikan 5\%. Pada pengujian dua pihak dengan signifikansi sebesar 0.000. Kriteria pengujian menggunakan uji dua pihak yaitu, jika $t_{h}<$ $\mathrm{t}_{\mathrm{t}(\alpha=0,05)}$ maka $\mathrm{H}_{0}$ diterima dan $\mathrm{H}_{1}$ ditolak dan jika $t_{h}>t_{t(\alpha=0,05)}$ maka $\mathrm{H}_{1}$ diterima dan $\mathrm{H}_{0}$ ditolak. Oleh karena nilai $\mathrm{t}$ hitung = $9.354>\mathrm{t}$ tabel $=1.943$ berarti $\mathrm{H}_{1}$ diterima dan $\mathrm{H}_{0}$ ditolak atau $0,000<0,05$ berarti $\mathrm{H}_{0}$ ditolak dan $\mathrm{H}_{1}$ diterima, berarti ada pengaruh olahraga tradisional polisi vs maling terhadap kecepatan lari 40 meter pada siswa kelas V SD Negeri 029 Loa Janan.

Tabel 4. Sampel T-Test Pada Hasil

Eksperimen Tes Awal dan Tes Akhir

\begin{tabular}{c|c|c|c|c|c}
\hline $\begin{array}{c}\text { Variab } \\
\text { el }\end{array}$ & Mean & SD & $\begin{array}{c}\text { t- } \\
\text { hitun } \\
\text { g }\end{array}$ & $\begin{array}{c}\text { t-tabel } \\
(0,05: 5 \\
)\end{array}$ & Sig \\
\hline B1 - B2 & 0.051 & 0.0 & 7.348 & 2.015 & .0 \\
& & 17 & & & 01 \\
\hline
\end{tabular}


Dari hasil pengujian hipotesis komparatif rata-rata dua sampel pada tabel 4 di atas diperoleh rata-rata sebelum dan sesudah diberi perlakuan berupa olahraga tradisional bentengan sebesar $=$ 0.051 dengan standar deviasi $=0.017, \mathrm{t}-$ hitung $=7.348$ dengan derajat kebebasan 5 pada taraf signifikan 5\%. Pada pengujian dua pihak dengan signifikansi sebesar 0.001. Kriteria pengujian menggunakan uji dua pihak yaitu, jika $\mathrm{t}_{\mathrm{h}}<\mathrm{t}_{\mathrm{t}(\alpha=0,05)}$ maka $\mathrm{H}_{0}$ diterima dan $\mathrm{H}_{1}$ ditolak dan jika $\mathrm{t}_{\mathrm{h}}>$ $\mathrm{t}_{\mathrm{t}(\alpha=0,05)}$ maka $\mathrm{H}_{1}$ diterima dan $\mathrm{H}_{0}$ ditolak. Oleh karena nilai t hitung $=7.348>\mathrm{t}$ tabel $=2.015$ berarti $\mathrm{H}_{1}$ diterima dan $\mathrm{H}_{0}$ ditolak atau 0,001 $<0,05$ berarti $\mathrm{H}_{0}$ ditolak dan $\mathrm{H}_{1}$ diterima, berarti ada pengaruh olahraga tradisional bentengan terhadap kecepatan lari 40 meter pada siswa kelas $V$ SD Negeri 029 Loa Janan.

Tabel 5. Independent Sample Test

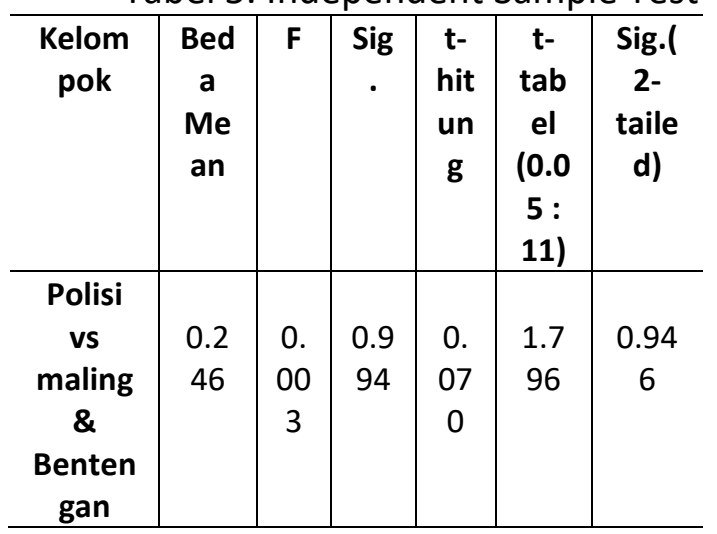

Pada tabel 5 pengujian hipotesis dua sampel independent, hasil lari $\mathbf{4 0}$ meter yang diberi perlakuan berup aktivitas olahraga tradisional polisi vs maling dan bentengan diperoleh $\mathrm{t}$ hitung $=0.070$, derajat kebebasan 11, perbedaan rata-rata 0.246, dengan kesamaan ragam $=0.994$ dan signifikansi 0.946. Kriteria pengujian menggunakan uji dua pihak yaitu, jika $t_{h}<$ $\mathrm{t}_{\mathrm{t}(\alpha=0,05)}$ maka $\mathrm{H}_{0}$ diterima dan $\mathrm{H}_{1}$ ditolak dan jika $t_{h}>t_{t(\alpha=0,05)}$ maka $\mathrm{H}_{1}$ diterima dan $\mathrm{H}_{0}$ ditolak. Oleh karena nilai $\mathrm{t}$ hitung = 0 . $070<\mathrm{t}$ tabel 1.796 berarti $\mathrm{H}_{0}$ diterima dan $\mathrm{H}_{1}$ ditolak atau 0,960 $>0,05$ berarti $\mathrm{H}_{0}$ diterima dan $\mathrm{H}_{1}$ ditolak atau tidak ada perbedaan pengaruh antara polisi vs maling dengan bentengan terhadp kecepatan lari 40 meter pada siswa kelas $\mathrm{V}$ Sd Negeri 029 Loa Janan.

\section{PEMBAHASAN}

Olahraga tradisional polisi vs maling dan juga olahara gtradisional bentengan memiliki tujuan yang sama yaitu meningkatkan kecepatan lari 40 meter siswa kelas V sd Negeri 029 Loa Janan. Hasil menunjukkan bahwa tidak ada perbedaan pengaruh antara polisi vs maling dan bentengan terhadap kecepatan lari 40 meter pada siswa kelas $V$ SD negeri 029 Loa Janan.

Perbedaan pengaruh antara polisi vs maling dan bentengan terhadap kecepatan lari 40 meter pada siswa kelas $V$ Sd Negeri 029 Loa janan. Sesuai dengan hasil uji-t data tes akhir lari 40 meter pada kedua olahraga tradisional pada tabel pengujian hipotesis dua sampel Independent sample test, hasil lari 40 meter yang diberi perlakuan berupa olahraga tradisional polisi vs maling dan bentengan diperoleh $t$ hitung $=0,070$ dengan derajat kebebasan 11 , perbedaan rata-rata 0.246 , dengan standar kesalahan perbedaan $=0.994$, dan signifikansi 0.944 . Oleh karena nilai $t$ hitung $=0.070<$ nilai $\mathrm{t}$ tabel $=1.796$ berarti $\mathrm{H}_{0}$ diterima dan $\mathrm{H}_{1}$ ditolak atau 0.,9070 > 0.05 maka $\mathrm{H}_{1}$ ditolak dan $\mathrm{H}_{0}$ diterima. Sehingga tidak ada perbedaan pengaruh antara olahraga tradisional polisi vs maling dan olahraga tradisional bentengan terhadap kecepatan lari 40 meter pada siswa kelas V Sd Negeri 029 Loa janan dikarenakan kedua olahraga tradisional ini baik polisi vs maling maupun olahraga tradisional bentengan sama-sama bisa meningkatkan kecepatan lari siswa khususnya lari cepat 40 meter ( sprint).

Mengapa tidak ada perbedaan karena masing-masing kedua olahraga tradisional ini memang mempunyai 
persamaan yaitu sama-sama mengarah atau lebih banyak aktivitasnya itu lari dan juga memerlukan kecepatan dari tiap pemainnya jadi tidak menuntut kemungkinan bahwa keduanya mampu meningkatkan kecepatan lari siswa. Semakin sering siswa itu berlari maka semakin meningkat pula kecepatan lari siswa tersebut.

Aktivitas olahraga tradisional polisi vs maling maupun bentengan sama-sama memiliki keterkaitan dengan lari, dengan diberikannya sebuah olahraga tradisional polisi vs maling maupun olahraga tradisioanl bentengan ke siswa sd secara terprogram atau rutin maka dengan sendirinya kecepatan lari siswa pasti akan meningkat dan minat siswa akan pelajaran atau olahraga akan semakin meningkat.

\section{KESIMPULAN DAN SARAN Kesimpulan}

Berdasarkan analisis data dan pembahasannya, maka hasil penelitian ini dapat disimpulkan sebagai berikut :

1. Ada pengaruh aktivitas olahraga tradisional polisi vs maling terhadap kecepatan lari 40 meter pada siswa kelas V SD Negeri 029 Loa Janan.

2. Ada pengaruh aktivitas olahraga tradisional bentengan terhadap kecepatan lari 40 meter pada siswa kelas V SD Negeri 029 Loa Janan.

3. Tidak ada perbedaan pengaruh antara olahraga tradisional polisi vs maling dan bentengan terhadap kecepatan lari 40 meter pada siswa kelas V SD Negeri 029 Loa Janan.

\section{Saran}

Berdasarkan kesimpulan penelitian di atas, ada beberapa saran yang dapat diberikan oleh penulis berkenaan dengan hasil penelitian ini adalah sebagai berikut:

1. Bagi guru olahraga di sekolah agar bisa memperkenalkan kembali tentang olahraga tradisional yang lainnya kepada siswa/ siswi yang ada di sekolah.

2. Kepada guru olahraga untuk dapat menjadikan hasil penelitian ini sebagai acuan dalam mengajar khususnya dalam meningkatkan kecepatan lari siswa di sekolah.

3. Dengan memasukan unsur budaya, dapat menjadikan sebuah pembelajaran pendidikan jasmani menjadi menyenangkan dan menarik antusias siswa, banyak sekali permainan tradisional yang bisa diterapkan pada saat pembelajaran jasmani dan selain itu juga dapat mengingatkan akan kultur atau budaya Indonesia.

\section{DAFTAR PUSTAKA}

Aji, Sukma. 2016. Buku Olahraga Paling Lengkap. Jakarta: ILMU.

Arikunto, Suharsimi, 2010. Prosedur Penelitian Suatu Pendekatan Praktek. Jakarta : Penerbit Rhineka Cipta.

Eddy Purnomo, M.Kes. 2011. Dasar- Dasar Gerak Atletik. Yogyakarta : Penerbit Alfamedia.

Hamdani,Ajun,2010.Olahraga tradisional balambat di Kecamatan Ungaran Timur Kabupaten Semarang - Jawa Tengah. Journal of sport sciences and fitness. 3 (1) : 14.

Iskandar Harris. 2017. Modul Sehat Bugar Untuk Tua Muda. Jakarta : Kementrian Pendidikan dan Kebudayaan.

Ismail, F. P., Arwin, A., \& Sugihartono, T. (2017). Perbedaan Latihan Naik Turun Tangga Tunggal (Satu Tangga) Dengan Naik Turun Tangga Jamak (Enam Tangga) Terhadap Kemampuan Lari Sprint 60 Meter Siswa Kelas V Sd Negeri 69 Kota Bengkulu. Kinestetik, 1(1). 
M. Husna. A, 2009. 100+ Permainan Tradisional Indonesia. Yogyakarta: CV Andi Offset (Penerbit Andi).

Nurhasan. 2000. Tes dan Pengukuran Pendidikan Olahraga. Jakarta: Direktorat Jenderal Olahraga.

Prayitno, B. A., \& Arwin, A. (2019). Meningkatkan Pembelajaran Lari Jarak 60 Meter Dengan Media Yang Dimodifikasi Siswa Kelas Xi Ips 1 Ta 2018/2019 Sma Negeri 7 Kota Bengkulu. Kinestetik, 3(1), 34-41.

Pristiyanto Arief, Soegiyanto, Sugiarto. 2014. Olahraga tradisional balambat di Kecamatan Ungaran Timur Kabupaten Semarang - Jawa Tengah. Journal of sport sciences and fitness. 3 (1) : 14.

Ruslan, Huda Samsul (2019) Penerapan metode bermain dalam meningkatkan hasil belajar. Jurnal Halaman Olahraga Nusantara : Jurnal Ilmu Keolahragaan, 2 (1), 10-20.

Ruslan, Hamdiana (2019) Learning Results Dribbling Handball through The Application Of Methods Of Play. Jurnal of physics : conference series, 1318012013, 1-4.

Sofiana Fela, Junaidi Said. 2015. Permainan tradisional kuntulan di desa Kalipancur Kecamatan Blado Kabupaten Batang Jawa Tengah. Journal of sport sciences and fitness. 4 (1) :

12.

Sugiyono. 2013. Metode Penelitian Kuantitatif Kualitatif dan R\&D. Bandung:Alfabeta.

Wiradihardja Sudrajat dkk. 2017. Buku Pendidikan Jasmani, Olahraga dan Kesehatan. Jakarta : Pusat Kurikulum dan Perbukuan, Balitbang, kemendikbud. 